\title{
DESVELANDO AS TRANSFORMAÇÕES DO ESPAÇO DO ALIMENTO DENTRO DOS APARTAMENTOS NA CIDADE DE VITÓRIA DURANTE A VIRADA DO SÉCULO XX
}

\author{
Paulo Cesar Scarim ${ }^{1}$ \\ Erick Alessandro Schunig F.
}

Resumo: A produção da cidade vem sendo realizada a partir de diretrizes que se coadunam com a sociedade de consumo. Nela o apartamento residencial tem seu interior submetido a uma racionalidade que revela aspectos inerentes a esse espaço urbano, tal qual nossa relação com a alimentação. Este estudo visa desenvolver uma análise da cozinha como um espaço indicador de transformações urbanas na cidade de Vitória e sua relação com a sociedade de consumo. Além de autores que versam sobre o tema, utilizamos como elemento de análise as propagandas imobiliárias das décadas 1980 e 1990, período em que envolvem se profundas transformações na capital do capixaba. Ao final estabelecemos considerações indicativas de que a transformação da cozinha revela aspectos da estratégia de agentes imobiliários, que abrange um novo conceito sobre a nossa relação com o alimento.

Palavras-chave: alimento; espaço urbano; propaganda.

\section{UNVEILING THE TRANSFORMATIONS OF FOOD SPACE INSIDE THE APARTMENTS IN THE CITY OF VITÓRIA DURING THE TURN OF THE 20TH CENTURY}

\begin{abstract}
The production of the city has been carried out based on guidelines that are in line with the consumer society. In it the residential apartment has its interior submitted to a rationality that reveals aspects inherent to this urban space, just like our relationship with food. This study aims to develop an analysis of the kitchen as an indicator space for urban transformations in the city of Vitória and its relationship with consumer society. In addition to authors dealing with the theme, we used as an element of analysis the real estate advertisements of the 1980s and 1990s, a period in which deep changes took place in the capital of the state of Espírito Santo. In the end, we established considerations that the transformation of the kitchen reveals aspects of the strategy of real estate agents, which encompasses a new concept about our relationship with food.
\end{abstract}

Keywords: food; urban space; advertising.

\footnotetext{
${ }^{1}$ Professor adjunto da Universidade Federal do Espírito Santo. pauloscarim@ hotmail.com.

${ }^{2}$ Universidade Federal do Espírito Santo. erasfe@yahoo.com.br

Estudos Geográficos, Rio Claro, 16(2): 64-86, jul./dez. $2018 \quad$ (ISSN 1678 -698X)

http://www.periodicos.rc.biblioteca.unesp.br/index.php/estgeo
} 


\section{INTRODUÇÃO}

No contexto que envolve a produção do espaço urbano, acreditamos ser possível considerar o debate sobre alimentação como uma temática de ampla relevância, principalmente ao analisarmos a dinâmica que envolve a sociedade de consumo e sua influência sobre as nossas relações.

Faz-se necessário pensar sobre qual é a projeção dessa influência no tocante à nossa relação com a alimentação, bem como a representação da cozinha dentro da habitação. Assim, partimos a nossa análise de uma questão importante, na qual indagamos como a cozinha deixou de ser um espaço central na vida das pessoas, com todos os seus significados materiais e imateriais, para se tornar um mero item diferenciado dentro da moradia.

Acreditamos que as transformações que incidiram sobre essa parte da habitação apresentam indicativos de modificações que são de ordem global e abarcam aspectos como: a produção de alimentos inserida da lógica do consumo, a introdução de novos hábitos alimentares, a elaboração de um cotidiano adaptado aos ditames do Capitalismo, a questão de gênero no tocante ao espaço do alimento, dentre outros temas que vêm sendo objeto de debate. Tais elementos revelam aspectos concernentes a mudanças incutidas na sociedade, que remetem à maneira como interagimos atualmente.

$\mathrm{Na}$ realidade aqui estudada a cozinha vem sendo modificada a partir das estratégias estabelecidas pelo setor da construção imobiliária e de outros segmentos econômicos, abarcando novos conceitos que se coadunam com suas estratégias de produção. Este artigo dialoga com trabalhos anteriores (SCHUNIG F. e SCARIM, 2017; SCHUNIG F., 2014) nos quais se desenvolveu uma análise sobre a importância da propaganda como estratégia de viabilização das formas de construção para habitação na cidade de Vitória, visando a compreender a transformação da cozinha a partir das estratégias estabelecidas pelo setor da construção imobiliária e de outros setores da indústria.

Entre os procedimentos metodológicos utilizados, realizamos um levantamento qualitativo de propagandas veiculadas em edição dominical de jornal de grande circulação no Espírito Santo. Ressaltamos que os anúncios utilizados neste artigo constituem-se num elemento empírico de análise, sendo estes indicativos de transformações ocorridas no período estudado. Optamos por selecionar os anúncios mais representativos, já que este estudo deriva de uma dissertação de mestrado. O parâmetro de seleção das propagandas teve como critério a escolha de anúncios a partir de 1/4 da página, com uma metragem de 3X13 $\mathrm{cm}$ de uma página no formato tabloide.

Para este trabalho, utilizamos informações de propagandas coletadas entre as décadas de 1980 e 1990. A escolha dessas décadas se justifica pelas transformações do setor da construção imobiliária voltado para habitação na cidade de Vitória, que estão ligadas às modificações ocorridas nos meios urbano e rural.

Essas décadas também se caracterizam por mudanças no setor da construção imobiliária em todo pais, dentre as quais destacamos a crise econômica na década de 1980 e, posteriormente, a estabilização financeira e a elaboração pelo Estado de instrumentos jurídicos e financeiros nos anos de 1990, visando à proteção e à capitalização desse setor. Esse período também se destaca pela valorização da propaganda como uma importante ferramenta para viabilização de novos produtos

Estudos Geográficos, $\quad$ Rio $\quad$ Claro, $\quad 16(2)$ : $\quad 64-86, \quad$ jul./dez. $2018 \quad$ (ISSN 1678 -698X) http://www.periodicos.rc.biblioteca.unesp.br/index.php/estgeo 
imobiliários, na qual se percebe a relação existente entre as mudanças envolvendo a cozinha como espaço do alimento e as transformações urbanas na cidade de Vitória.

Como referência teórica, utilizamos o aporte de autores como: Fishler (1995), Staszak (2001), Poulain (2001), Barthes (1980), Bourdieu (2007), Harvey (2013), Lefebvre (2008a; 2008b; 2000) e Ritzer (1996), que forneceram subsídios para a discussão referente à relação entre alimentação e produção imobiliária. No tocante ao debate sobre a modernidade alimentar e à relação entre personalização e a utilização do marketing e da propaganda na produção imobiliária, valemo-nos do arcabouço de Poulain (2001), Baudrillard (2007; 1991) e Costa (2002). Em relação a análise das transformações dos meios rural e urbano e à influência na produção do espaço da cidade de Vitória no período estudado, baseamo-nos nos trabalhos de Scarim (2006), Campos Júnior (2002), Reis (2007), Botelho (2007) e Schunig F. (2014).

Ao final foi possível realizar uma análise sobre os aspectos que envolvem as mudanças na cozinha dos apartamentos residenciais na cidade de Vitória, aplicada às estratégias elaboradas pelos agentes imobiliários. Tais aspectos apresentam indicativos de uma conexão entre a produção do espaço urbano da capital capixaba e uma nova lógica do cotidiano que envolve nossa relação com o alimento.

\section{A RACIONALIZAÇÃO E SIGNIFICADO DA COZINHA}

$\mathrm{Na}$ perspectiva que envolve este trabalho, acreditamos serem necessárias algumas considerações iniciais sobre a motivação que nos leva a avaliar a importância da cozinha como um espaço que dialoga com as transformações da sociedade de consumo. Num primeiro momento, observamos poucos trabalhos em relação a esse tema, bem como uma abordagem que contemple uma discussão sobre o espaço doméstico.

No tocante ao espaço doméstico, sua abordagem implica um debate que abarca uma conexão com a produção do cotidiano que não se limita à vida privada. Nesse aspecto, Staszak (2001, p. 340) atenta para certa negligência das ciências sociais envolvendo uma análise do espaço doméstico, mesmo sendo este um local onde passamos uma parcela considerável do nosso tempo e no qual ocorrem eventos importantes em nossa vida. Sua organização remete a uma escala, na qual a sua metragem projeta e opera a partir de uma relação com nosso corpo.

É um território fundamental onde emoções e memórias estão presentes, expressando a forte ligação entre a identidade e o território envolvido na consciência individual (STASZAK, 2001, p. 346). Ao mesmo tempo é admissível perceber o espaço doméstico como um espelho no qual é possível ver estruturas e valores essenciais da sociedade. É nele que se insere a estrutura da família, as oposições de gênero, as normas sexuais, as formas de produção econômica, as concepções do privado e do público, a visão de mundo, o relato do meio, dos gostos e desgostos e das ideologias que se traduzem na organização do espaço doméstico.

Entre as várias possibilidades analíticas que abrangem o espaço doméstico, a cozinha se constitui num espaço que se conecta diretamente com as transformações da sociedade de consumo, ao passo que é adaptada ao cotidiano produzido pela mesma. Nela as relações sociais são influenciadas por diversos segmentos da indústria, tornando a alimentação um ato cada vez mais corriqueiro ou submetido a signos que convidam o consumidor a adentrar num universo de "paladares refinados".

Estudos Geográficos, Rio Claro, 16(2): 64-86, jul./dez. $2018 \quad$ (ISSN 1678 -698X) http://www.periodicos.rc.biblioteca.unesp.br/index.php/estgeo 
Ao nos propormos a analisar a cozinha dos apartamentos da cidade de Vitória lançados no final do século $X X$, percebemos que tal discussão abrange elementos que permeiam aspectos concernentes à difusão de valores que dialogam com vários segmentos, dentre eles o setor da construção imobiliária. Importante ressaltar que, ao falarmos de setor da construção imobiliária neste estudo, estamos nos referindo a um segmento complexo, que envolve a atuação de diversos agentes como: construtores, incorporadores, proprietários de terras, vendedores, dentre outros agentes que integram a cadeia produtiva do segmento imobiliário (BOTELHO, 2007, p.25).

No tocante as ações do referido setor, percebemos que suas atividades têm sido norteadas por estratégias que buscam viabilizar seu produto final, o imóvel. Num primeiro momento, partimos da ideia de que o seu processo produtivo está ligado a mecanismos fundamentais para o seu desenvolvimento, dentre os quais destacamos as possibilidades que envolvem a renda da terra. Nesse sentido, 0 aporte teórico de Marx (apud BOTELHO, 2007, p. 73) no tocante à renda de monopólio oferece subsídios para uma discussão inicial, na medida em que agentes imobiliários atuam a partir da possibilidade de rendimentos crescentes, por intermédio de preços que levam em consideração as particularidades existentes num local.

À medida que tais preços são determinados pelo desejo e a capacidade de pagamento dos compradores, sem depender do preço geral de produção ou do valor dos produtos, a renda de monopólio se constitui num fator estratégico para projeção de rendimentos de um setor cuja reprodução do capital obedece a várias etapas até a comercialização do seu produto final.

Contudo, acreditamos que discutir renda de monopólio é também pensar nas possibilidades que envolvem a apropriação de outros elementos que visam à apresentação de uma mercadoria a partir de qualidades que seriam únicas. Singularidades que almejam tornar um produto alçado a categoria de "especial", através de elementos que não se restringem ao espaço físico.

Esses elementos se embrenham mais profundamente em nossas relações sociais à proporção que são alçados a uma condição de singularidade, seja por sua escassez, seja pela sua ressignificação. Lembramos aqui um indicativo de Lefebvre (2008b, p.33), ao observar que as estratégias elaboradas por agentes não visam simplesmente à venda do imóvel; antes, compreendem a difusão de um conceito de urbanismo no qual o habitat se insere como lugar de felicidade, numa vida cotidiana miraculosa e maravilhosamente transformada.

Esse urbanismo se vale de elementos relevantes da nossa vivência. Nesse aspecto, Harvey (2013, p.139) considera a utilização do imaterial, pelo viés da possibilidade que envolve a inserção de bens culturais que se tornaram raridades em função da dinâmica da sociedade atual. Ao percebermos um bem cultural como passível de ser explorado, no sentido que envolve a obtenção de renda de monopólio, consideramos a possibilidade de inserir a nossa relação com a alimentação como um item suscetível de apropriação, que pode materializar-se no espaço concebido, tal qual a cozinha.

Como nos indica Lefebvre (2000, p.70), o espaço pode ser analisado a partir da tríade percebido-concebido-vivido. Compreendemos a cozinha como um espaço que remete a uma percepção e a uma vivência sobre o significado do alimento que transcende o simples ato de consumo, pois abrange também a remissão de lembranças, as tradições culinárias, a convivência e o lazer. Todavia, entender a

Estudos Geográficos, $\quad$ Rio $\quad$ Claro, $\quad 16(2): \quad 64-86, \quad$ jul./dez. $2018 \quad$ (ISSN 1678 -698X) http://www.periodicos.rc.biblioteca.unesp.br/index.php/estgeo 
cozinha como um item específico de uma habitação passa pela compreensão do seu significado atualmente, que o inclui como espaço concebido.

Dessa forma, acreditamos que o debate acerca da representação espacial envolve elementos que versam sobre a relação de como o espaço é percebido, bem como onde se insere a vivência e o papel que desempenha ao se materializar como espaço concebido. Ao entramos nesta discussão, destacamos a contribuição da semiologia alusiva aos estudos de Barthes (1980) acerca do mito, visto que sua produção esteja associada à ideia da formação de uma linguagem-objeto dotada de signos.

Barthes (1980, p.152) define o mito como um roubo de linguagem, cuja função é transformar o sentido em forma, não negando as coisas, mas sim inocentando-as. Assim, extingue a complexidade dos atos humanos, conferindo-lhes a simplicidade das essências ao suprimir a dialética e organizar um mundo sem contradições. Uma vez que o mito estabelece esse processo de organização, passa a realçar ou obliterar elementos que nos cercam, apresentando uma realidade a partir de uma seleção de elementos que exclui a complexidade que envolve as relações sociais.

Seguindo essa linha de raciocínio, indagamos acerca da dimensão que o mito ocupa ao falarmos da cozinha como espaço do alimento atualmente. Essa questão nos insere num debate entre a nossa relação atual com o alimento e a perspectiva que a cozinha ocupa num imóvel como o apartamento residencial, cuja forma estabelece um diálogo com a racionalidade espacial incorporada pelo processo produtivo imobiliário, que remete a uma lógica de funcionalidade e flexibilização do espaço interno (SCHUNIG F.; SCARIM, 2017, p. 101).

Numa abordagem alusiva à afinidade entre racionalidade e espaço, Fischler (1995, p. 183) ressalta que a questão alimentar se insere como um importante componente no tocante às novas relações entre individualidade e comunidade, a partir da influência da urbanização e da técnica, desde a segunda metade do século $X X$. Segundo ele, há um enfraquecimento dos laços sociais que podem ser verificados através dos novos hábitos alimentares, agora são subordinados a produção industrial dos alimentos e a um tempo cada vez maior destinado a intensa rotina do trabalho e de outros aspectos que caracterizam a produção do cotidiano.

Esse processo reflete uma lógica de vida pautada por concepções de uma racionalização formal que domina a vida moderna. Entendemos a racionalização aqui como a busca por meios otimizados que levem a um determinado fim, envolvendo disposições legislativas, regulamentos e estruturas sociais (RITZER, 1996, p.35).

Segundo Ritzer (1996, p. 35) a racionalização formal não permite que os indivíduos se concentrem em seu próprio arbítrio a fim de buscarem os melhores meios para atingirem um determinado objetivo. Em vez disso, são conduzidos por regras, regulamentos ou métodos. Essa racionalização vem influenciando sobremaneira a nossa relação com o alimento, quanto ao tipo e ao local onde o consumimos. Em sua abordagem sobre a ideia de uma "Macdonaldização da sociedade", Ritzer (1996, p.29) aponta para a influência desses sistemas de racionalização visando à eficiência, à previsibilidade, ao cálculo e ao controle em nossa relação com o alimento.

Tais sistemas de racionalização tornam os serem humanos irracionais a ponto de questionarem a própria humanidade. O que seria um fast food senão um simulacro de uma linha de montagem, na qual um grupo de pessoas se aglomera

Estudos Geográficos, Rio Claro, 16(2): 64-86, jul./dez. $2018 \quad$ (ISSN $\quad$ 1678-698X) http://www.periodicos.rc.biblioteca.unesp.br/index.php/estgeo 
numa fila para se alimentar (RITZER, 1996, p.28). Ou mesmo a produção de um hambúrguer, cuja preparação também lembra uma linha de montagem. O consumo de alimentos num fast food nos lembra de que estamos insertos num tipo de cadeia produtiva.

A crítica de Ritzer (1996), sobre a racionalização envolvendo a alimentação nos remete ao debate de Barthes (1980) sobre o mito, mais especificamente a relação existente entre o significante e o significado na formação do mito. Segundo Barthes (1980, p.139), o significante do mito apresenta-se de uma maneira ambígua, sendo simultaneamente sentido e forma. Enquanto sentido, o significante postula uma leitura em que a realidade sensorial ganha destaque, ao apreender com os olhos aquilo que nos é apresentado. Ao mesmo tempo, é dotado de conjuntos plausíveis que revelam uma racionalidade, ou seja, produz um sentido.

No caso do significado, Barthes (1980, p.140) o percebe como um conceito que restabelece uma cadeia de causas e efeitos, de motivações e de intenções. Mediada pelo conceito, toda uma história nova é implantada no mito. No caso da alimentação, os sistemas de racionalidade nos apresentam signos cujos significados e significantes nos transportam para a idealização da vida moderna por meio da criação de mitos, tal como a praticidade do fast food ou dos supermercados.

No tocante aos supermercados, estes se tornaram equipamentos essenciais à vida moderna, constituindo-se num espaço da mercadoria onde se elabora uma nova sociedade (BAUDRILLARD, 1991, p. 97). Esse equipamento adquiriu uma importância tamanha na sociedade atual que abrange desde os processos de centralização e redistribuição de mercadorias numa região até a sua influência na racionalização do tempo, nas práticas e nos percursos do consumidor. A ele, as pessoas se dirigem para se encontrar, selecionar objetos e personalizar suas existências.

Falar de supermercado é também adentrar a esfera do mito, na medida em que remete à noção de bem-estar e de atendimento às necessidades, cuja função ideológica envolve a reabsorção e supressão das determinações objetivas, sociais e históricas, da desigualdade (BAUDRILLARD, 2007, p.48). Sua conotação coloca-o num patamar de equipamento prioritário para o abastecimento das residências, sendo algo que não passou despercebido pelos agentes da construção imobiliária.

Numa sociedade cada vez mais urbanizada, na qual as pessoas são dominantes pelos ditames de um cotidiano submetido à racionalidade formal, habitar próximo a um supermercado passou a ser um diferencial para a comodidade de buscar o alimento ou acessar outro produto que esteja ali, à disposição do consumidor.

Dessa forma, é possível perceber que a alimentação se insere na produção do espaço urbano, já que a cozinha estabelece uma relação com itens agora alçados à categoria de essenciais à vida moderna e que indica aspectos de como nos alimentamos e de como nos relacionamos. Assim é possível perceber a cozinha não somente como um espaço do alimento voltado ao habitat, mas, também, como um item atrelado a diversas cadeias produtivas da sociedade de consumo.

\section{A MODERNIDADE ALIMENTAR E A PERSONALIZAÇÃO DO ESPAÇO}

Entender o papel que a cozinha representa atualmente no contexto que envolve o espaço urbano é compreender como ela é percebida. Assim, adentramos

Estudos Geográficos, Rio Claro, 16(2): 64-86, jul./dez. $2018 \quad$ (ISSN $\quad$ 1678-698X) http://www.periodicos.rc.biblioteca.unesp.br/index.php/estgeo 
um debate sobre a nossa relação atual com a alimentação. Numa análise sobre essa relação, Poulain (2001, p. 12) nos lembra das mudanças incutidas na sociedade de consumo que se arraigaram com mais intensidade no final do século $\mathrm{XX}$.

Segundo Poulain (2001, p. 9) a experiência da alimentação tornou-se cientificamente racionalizada, com base numa forma de organização do mundo que teria mudado o nosso comportamento a partir de uma ideia de "modernidade alimentar". Nessa modernidade são introduzidas políticas de saúde nutricionais, programas de educação e novos conceitos gastronômicos que nos levam a uma nova relação com o alimento.

Essa modernidade é corroborada pela ciência por meio de argumentos racionais e incentivada pelo mercado por intermédio da apresentação de novos produtos. Contudo, o junk food continua abalando as certezas ocidentais da sociedade moderna no tocante à escolha alimentar (POULAIN, 2001, p.10).

De acordo com Poulain (2002, p.12) uma dieta saudável indicada pela ciência pode conviver com o processamento industrial de alimentos, aventando também a possibilidade de alçar as tarefas culinárias a um elemento de lazer. A globalização vem produzindo uma dieta moderna que ao mesmo tempo em que difunde e padroniza gostos, também produz diferenciações, contradições e conflitos. A existência de produtos de terroir, a criação de cozinhas ditas "regionais" (POULAIN, 2002, p.10), bem como os selos de Indicação Geográfica de Origem, as Certificações Orgânicas e Agroecológicas, os circuitos curtos, a proliferação de feiras, dentre outras iniciativas, demonstram elementos contraditórios aos Impérios Agroalimentares (PLOEG, 2008)

É possível enxergar dentro dessa modernidade, mecanismos que promovem não somente a padronização, mas também a distinção. Para Bourdieu (2007, p. 13), um dos elementos de distinção entre grupos sociais envolve a produção de uma estética, associando-os a diferentes posições sociais. Segundo ele, o gosto é um desses elementos, pautando classificações para aqueles que transitam entre o gosto da necessidade e o gosto da liberdade ou do luxo, que se opõe à comezaina popular.

Todavia, Bourdieu (2007) ressalta que o gosto como um elemento estético de diferenciação entre grupos envolve escolhas, nas quais o mito desempenha um papel importante extraordinário, visto que os signos possuem significados diversos, apresentados sobre diferentes formas e sentidos. O gosto converge para a ideia de personalização na qual afloram o desejo, a descoberta e a individualidade.

Ao discorrer sobre a personalização, Baudrillard (2007, p.88) atenta para a influência do mito como organizador do sujeito através de signos que recriam uma individualidade. Uma individualidade em que a sociedade de consumo ganha importância a partir da introdução de diferenças e hierarquias e que se coaduna com a produção capitalista.

A sociedade de consumo possibilita personalizar uma habitação, como um apartamento, ou mesmo a nossa alimentação, tais quais as exigências de uma dieta da moda ou a escolha que fazemos ao adentrar um supermercado. O que dizer então da cozinha, cuja forma vem sendo apresentada a partir de novos conceitos estabelecidos pelo setor imobiliário? Essa indagação também é concernente à personalização que envolve outros produtos de segmentos industriais, como eletrodomésticos e alimentos processados.

Estudos Geográficos, $\quad$ Rio $\quad$ Claro, $\quad 16(2): \quad 64-86, \quad$ jul./dez. $2018 \quad$ (ISSN $\quad 1678$-698X) http://www.periodicos.rc.biblioteca.unesp.br/index.php/estgeo 
A diferenciação e a personalização são aspectos ideológicos nos quais se naturaliza a hierarquia e ao mesmo tempo a homogeneização do sujeito. O apelo ao consumo passa a ser o indutor da diferença e de como se dão as relações. Seus signos passam a ser "flutuantes", baseados numa retórica que se vale de uma representação buscando um significado concernente à lógica mercantil.

Essa retórica de apelo ao consumo produz uma obliteração que abrange a maneira como percebemos o urbano, forjado pela prática e pela teoria da industrialização, que concebem o espaço a partir de um pensamento analítico fragmentário e redutor da realidade (LEFEBVRE, 2008a, p.161). Um aspecto importante para compreender a construção desse discurso diz respeito à propaganda $^{3}$ e ao marketing ${ }^{4}$, utilizados como importantes ferramentas para a difusão de novos hábitos de consumo.

Amplamente utilizadas por diversos segmentos econômicos, essas duas ferramentas estabelecem um diálogo direto com o sujeito a partir da criação de signos que denotam diferenciação e personalização do produto. Num setor como o da construção imobiliária, cuja produção envolve elementos complexos, a utilização de ambos ganhou vasta importância no final do século XX em nosso país.

Todavia, é interessante compreender como essas duas ferramentas atuam no processo produtivo imobiliário. Diante da possibilidade de obter preços de monopólio em razão de particularidades existentes na terra e de outros elementos já mencionados neste trabalho, os agentes do setor da construção imobiliária engendram ações, visando a obter rendimentos crescentes, que envolvem estratégias voltadas para apropriação de elementos diferenciais.

Autores como Jaramillo (1982, p. 156) e Topalov (1979, p. 135) observam que a terra se constitui em condição e meio de produção para o setor da construção imobiliária, tal como acontece em outros setores como a agricultura. Porém, no caso específico da produção imobiliária seu produto é único e imóvel. Sendo assim, o processo produtivo que envolve o setor da construção requer um novo solo a cada término, visando sempre à projeção de rendimentos crescentes.

Dentro do processo produtivo que envolve o imóvel, o capital ocupa um destaque primordial, uma vez que propicia ao seu detentor condições para sua reprodução e obtenção de rendimentos crescentes e de forma cada vez mais rápida. Essas condições possibilitam auferir lucro pela apropriação de parte da mais-valia e da renda oriunda da propriedade da terra.

Contudo, ao falarmos aqui de setor da construção imobiliária, percebemos que o seu processo produtivo envolve outros aspectos. No processo de produção do imóvel, Topalov (apud Costa, 2002, p. 45) observa que o capital percorre um ciclo na sua reprodução. Nesse ciclo, o capital-dinheiro transforma-se em meios de produção e força de trabalho que engendram um processo produtivo, resultando numa mercadoria com valor maior que os meios de produção e a força de trabalho, tendo, assim, produzido a mais-valia. A mercadoria é lançada em circulação, onde busca, com a venda, tornar novamente o capital e a mais-valia à forma capital-dinheiro, podendo assim renovar-se o ciclo e dar prosseguimento à acumulação.

\footnotetext{
${ }^{3}$ O uso do termo "propaganda" neste trabalho tem como referência o Conselho Executivo das Normas-Padrão (2003) das atividades publicitárias, cuja definição é: "qualquer forma remunerada de difusão de ideias, mercadorias, produtos ou serviços por parte de um anunciante identificado".

${ }^{4}$ No tocante ao marketing, Kotler (2000), o define como o conjunto de atividades que tem por objeto a facilidade e realização de trocas. Segundo este autor, o marketing pode ser visto como a tarefa de criar, promover e fornecer bens e serviços a clientes sejam pessoas físicas ou jurídicas.

Estudos Geográficos, Rio Claro, 16(2): 64-86, jul./dez. 2018 (ISSN 1678-698X)

http://www.periodicos.rc.biblioteca.unesp.br/index.php/estgeo
} 
Devido ao longo período que envolve o processo de produção do seu produto, os agentes do setor da construção imobiliária vêm empreendendo estratégias a fim de diminuir esse ciclo percorrido pelo capital através do aumento da velocidade das vendas, conseguir retorno rápido do seu capital e projetar rendimentos cada vez maiores.

Dessa forma, a propaganda e o marketing entraram como componentes essenciais visando a permitir a diminuição desse longo ciclo e procurando impulsionar a velocidade das vendas que envolve a comercialização do produto imobiliário. Para conseguir essa velocidade, tais ferramentas se valem de elementos que visam a sedução do consumidor a fim de atrai-lo e, dessa forma, aumentar as vendas.

Tal como apresentamos em trabalhos anteriores, a propaganda vem sendo utilizada pelo setor da construção imobiliária em décadas anteriores ao período desta pesquisa (SCHUNIG F.; SCARIM, 2017). Porém, em relação ao marketing, observamos que sua utilização nesse setor começou a acontecer a partir da segunda metade da década de 1990, pelas maiores empresas de São Paulo. O uso dessa ferramenta foi influenciado por um contexto no qual se identificam alguns fatores que contribuíram para essa mudança.

Em sua pesquisa, Costa (2002, p. 75) discorre sobre este tema, na qual observa que apesar de se tratar de um setor considerado conservador, no que tange à utilização de novos recursos para compreensão do mercado, construtoras e incorporadoras foram influenciadas pela crise no sistema de financiamento do Sistema Financeiro da Habitação (SFH), que as levou buscar novos mecanismos para sobreviver no mercado.

Costa (2002, p. 94) observa que as falências de incorporadoras e construtoras na década de 1990, o que acarretou enormes prejuízos aos consumidores e desconfianças com relação às empresas, ajudou a fortalecer a necessidade destas diretrizes. O autor também destaca a ocorrência de casos de desabamentos de condomínios verticais populares e de classe média - que instaurou uma insegurança no mercado - , bem como o aumento da concorrência, a partir da complexidade das operações do mercado a partir da criação do Sistema Financeiro Imobiliário.

Tais fatores concederam legitimidade a uma mudança organizacional na qual o marketing ganhou legitimidade dentro do setor imobiliário, passando a identificar nichos de mercado, criação de vantagens competitivas e de um preço de venda produzido pela prática da criação de diferenças e construção de identidades sociais (COSTA, 2002, p. 83).

No caso específico do setor da construção imobiliária capixaba, ressaltamos que, se a propaganda era uma ferramenta utilizada por esse setor desde décadas que antecedem os anos 80 (SCHUNIG F., 2014), o mesmo não se pode dizer do marketing, cuja utilização aconteceu na década posterior e que será objeto de outro estudo.

Visando à eficiência na representação dos diferenciais dos produtos imobiliários, o marketing e a propaganda tornaram-se mais incisivos na busca pelo consumidor. Não é apenas a localização e seus atributos que são ressaltados (SCHUNIG F. e SCARIM, 2017). Enfatizam-se pela propaganda os novos conceitos elaborados pelo marketing, como: o projeto arquitetônico, a marca da empresa, itens de lazer e segurança e até mesmo equipamentos (públicos e privados) ou áreas públicas. O produto passa a ser personalizado conforme o nicho identificado.

Estudos Geográficos, $\quad$ Rio $\quad$ Claro, $\quad 16(2): \quad 64-86, \quad$ jul./dez. $2018 \quad$ (ISSN $\quad 1678$-698X) http://www.periodicos.rc.biblioteca.unesp.br/index.php/estgeo 
No caso do projeto arquitetônico, novos conceitos são difundidos, estabelecendo um diálogo com a racionalidade formal do espaço interno do imóvel, no qual itens como cozinha sofrem transformações. Esta agora passa a ser associada a um estilo de vida intramuros, no qual o tempo passa a ser determinado pela fluidez da vida moderna. Estilo de vida cuja alimentação vem sendo determinada pelos ditames de uma sociedade urbana, no qual o indivíduo não dispõe de tempo suficiente para consumir alimentos, preferindo a rapidez e comodidade dos produtos industrializados.

No tocante a cidade de Vitória, observamos uma série de transformações que dizem respeito a sua expansão urbana e que se conectam a este novo estilo de vida. Estas mudanças estão intrinsecamente ligadas à transformação do meio rural capixaba, na qual um dos aspectos importantes envolve a produção e abastecimento.

\section{TRANSFORMAÇÕES NOS MEIOS RURAL E URBANO INFLUENCIANDO A CIDADE DE VITÓRIA}

O período que compreende as décadas de 1980 e 1990 abarca uma série de transformações no setor da construção imobiliária capixaba e consequentemente na forma como o espaço urbano da Vitória foi produzido. A fim de melhor identificálas, elencaremos as principais características desse período que envolve mudanças nos meios rural e urbano.

Conectado aos efeitos das políticas desenvolvimentistas no Brasil elaboradas ainda no governo militar, o meio rural capixaba na década de 1980 se caracterizou pela grande concentração fundiária e avanço de grandes monoculturas, como a cana-de-açúcar e o eucalipto, além da manutenção da monocultura cafeeira (SCARIM, 2006, p. 167). A lógica desenvolvimentista governamental implantada durante o governo militar privilegiou um modelo agroindustrial, que se consolidou nas décadas de 1980 e 1990.

Este modelo se baseou no domínio de grandes extensões de terras visando a uma ou a algumas empresas, com pouco emprego e, principalmente, não vinculadas ao uso da mão-de-obra e com a correlata habitação no campo. Uma consequência disso foi o aumento das migrações para a cidade, sobretudo para Vitória e demais municípios que integram a Região Metropolitana da Grande Vitória (RMGV) (SCARIM, 2006, p.160)

Todavia, as mudanças no campo não ocorreram de forma isolada. Atendendo às diretrizes da política do Plano Nacional de Desenvolvimento (PND), elaborado no governo militar, o Estado realizou várias intervenções nas áreas urbanas. Destacamos aqui a instalação de plantas industriais, com destaque para o setor siderúrgico, em municípios que compõem atualmente a RMGV (CAMPOS JÚNIOR, p.126).

Além de gerar empregos diretos, essa política de industrialização pautada pelos grandes projetos teve efeitos multiplicadores, influenciando na formação de uma classe média e se constituindo num importante vetor estruturador da produção e do consumo do espaço em função da indução contida na infraestrutura necessária à sua operação (CAMPOS JúNIOR, 2002, p. 127). Nesse sentido a cidade de Vitória, centro das decisões políticas do Estado e sede de várias empresas, adentrou os anos 80 como lugar privilegiado de moradia da população de maior renda e da classe média.

Estudos Geográficos, $\quad$ Rio $\quad$ Claro, $\quad 16(2)$ : $\quad 64-86, \quad$ jul./dez. $2018 \quad$ (ISSN 1678 -698X) http://www.periodicos.rc.biblioteca.unesp.br/index.php/estgeo 
Também se observam outras mudanças que conectaram a cidade de Vitória ao campo. Destacamos aqui influência da criação das Centrais de Abastecimento do Espírito Santo (Ceasa), em 1977, no abastecimento metropolitano, com uma crescente movimentação de produtos, destacando-se os hortifrutigranjeiros (SCARIM, 2006, p 174). Soma-se a essa medida a criação de outras estruturas como o Hortomercado da Praia do Suá, localizado em Vitória, e a popularização dos supermercados. Neste último percebemos uma associação direta à ideia de praticidade e personalização, mas também a necessidade de compras de alimentos para estoque devido à inflação na década de 1980.

A consequência dessas transformações no panorama econômico acarretou modificações na atuação do setor da construção imobiliária capixaba. No caso de Vitória, a mudança da base econômica e do processo migratório influenciou na disponibilidade de terras para construção imobiliária, cujas áreas começaram a diminuir, ao passo que se elevou o preço dos terrenos. Se até a década de 1970 o preço terra, que seria um obstáculo ao consumidor, diluído pela política de financiamento da habitação executada pelo Estado, favorecendo a atuação dos agentes imobiliários (CAMPOS JUNIOR, 2002, p. 128), o mesmo não ocorreu na década de 1980.

Os anos 80 se caracterizam pela espiral inflacionária cujos índices provocaram forte retração econômica e consequente inibição do consumo em todos os setores. No caso do setor imobiliário, essa década foi marcada pela crise no Sistema Financeiro da Habitação. Botelho (2007, p. 120) observou que após o fim do regime militar em 1985, a questão habitacional entrou num período de transição, caracterizado pela desarticulação institucional e aprofundamento da crise do financiamento habitacional até os anos 90 .

Um indicativo dessa mudança foi a extinção do Banco Nacional da Habitação (BNH), causada pelo aumento do déficit e problemas de correção das dívidas no Plano Cruzado em 1986 (BOTELHO, p. 120). Com a extinção do BNH, as atribuições e recursos passaram para a Caixa Econômica Federal, que herdou uma inadimplência bilionária das sociedades de crédito imobiliário, cooperativas habitacionais, bancos comerciais e associações de poupança e empréstimos.

A década de 1990 marcou um período de transição que abrange transformações na forma de financiamento para habitação. Um dos efeitos dessa transição teve início do Governo Collor (1990 a 1992) e se estendeu até o Governo Fernando Henrique Cardoso (1995 a 2002), no qual foram criadas medidas que colocaram a habitação de interesse social em segundo plano, privilegiando segmentos da população de maior renda (BOTELHO, 2007, p. 122).

Em contrapartida, a década de 1990 também é marcada por medidas que propiciaram segurança e capitalização ao setor da construção imobiliária. Dentre estas, Botelho (2007, p.126) destaca a criação do Sistema Financeiro Imobiliário (SFI), através da Lei 9.514/97. De acordo com este autor, as bases do SFI são a extensão da alienação fiduciária aos imóveis urbanos e a flexibilização dos contratos acertados entre as partes oferecendo maior garantia ao investidor e sustentabilidade financeira às operações contratadas.

Ainda segundo Botelho (2007, p. 126), a lei que criou o SFI introduziu também um novo veículo legal denominado Companhia Securitizadora de Créditos Imobiliários, com propósitos de fazer a securitização dos recebíveis imobiliários através de emissão dos Certificados de Recebíveis Imobiliários (CRIs), títulos

Estudos Geográficos, $\quad$ Rio $\quad$ Claro, $\quad 16(2): \quad 64-86, \quad$ jul./dez. $2018 \quad$ (ISSN 1678 -698X) http://www.periodicos.rc.biblioteca.unesp.br/index.php/estgeo 
equivalentes a debêntures. Tal medida possibilitou a criação de novos mecanismos para captação de recursos.

Esse fator, somado a conjuntura econômica favorável na década de 2000, fez com que o setor da construção imobiliária conseguisse superar obstáculos impostos ao seu crescimento. Se até a década de 1980 a expansão do setor e elevação de seus rendimentos tinha relação com as políticas habitacionais oriundas do Estado, a criação do SFI e de um instrumental financeiro possibilitou a aproximação com o mercado financeiro e, consequentemente, atrair capital para produção imobiliária.

Outro aspecto importante que se conecta a esses fatores diz respeito à dinâmica do mercado imobiliário na cidade de Vitória. Segundo Campos Júnior e Reis (apud SCHUNIG F., 2014, p. 120), o centro da capital capixaba, que nas primeiras décadas da segunda metade do século $\mathrm{XX}$ era a principal área de investimentos imobiliários, sofreu um processo de adensamento urbano que levou à perda de amenidades.

Isso induziu os agentes imobiliários a buscarem novas áreas para investimentos, que em Vitória se direcionaram à parte Norte do município, tal como o bairro Praia do Canto e bairros localizados próximo ao balneário de Camburi (Figura 1). A consequência foi a diminuição progressiva de empreendimentos imobiliários residenciais no Centro de Vitória até o final da década de 1980.

Também merece ressaltar a intervenção do Estado a partir da construção, nos anos de 1970, do aterro da Companhia de Melhoramentos e Desenvolvimento Urbano (Comdusa), que deu origem ao bairro Enseada do Suá, atualmente uma das áreas mais valorizadas da capital, contendo equipamentos como o Shopping Vitória (maior do Estado) e a Praça do Papa.

Outra intervenção importante foi a construção da ponte Deputado Darcy Castello de Mendonça. Iniciada na década de 1970 e finalizada na década de 1980, além de ligar as cidades de Vitória e Vila Velha, essa ponte também influenciou a dinâmica imobiliária em bairros localizados em suas proximidades, como Praia do Canto e Enseada do Suá.

Estudos Geográficos, $\quad$ Rio $\quad$ Claro, $\quad 16(2): \quad 64-86, \quad$ jul./dez. $2018 \quad$ (ISSN 1678 -698X) 


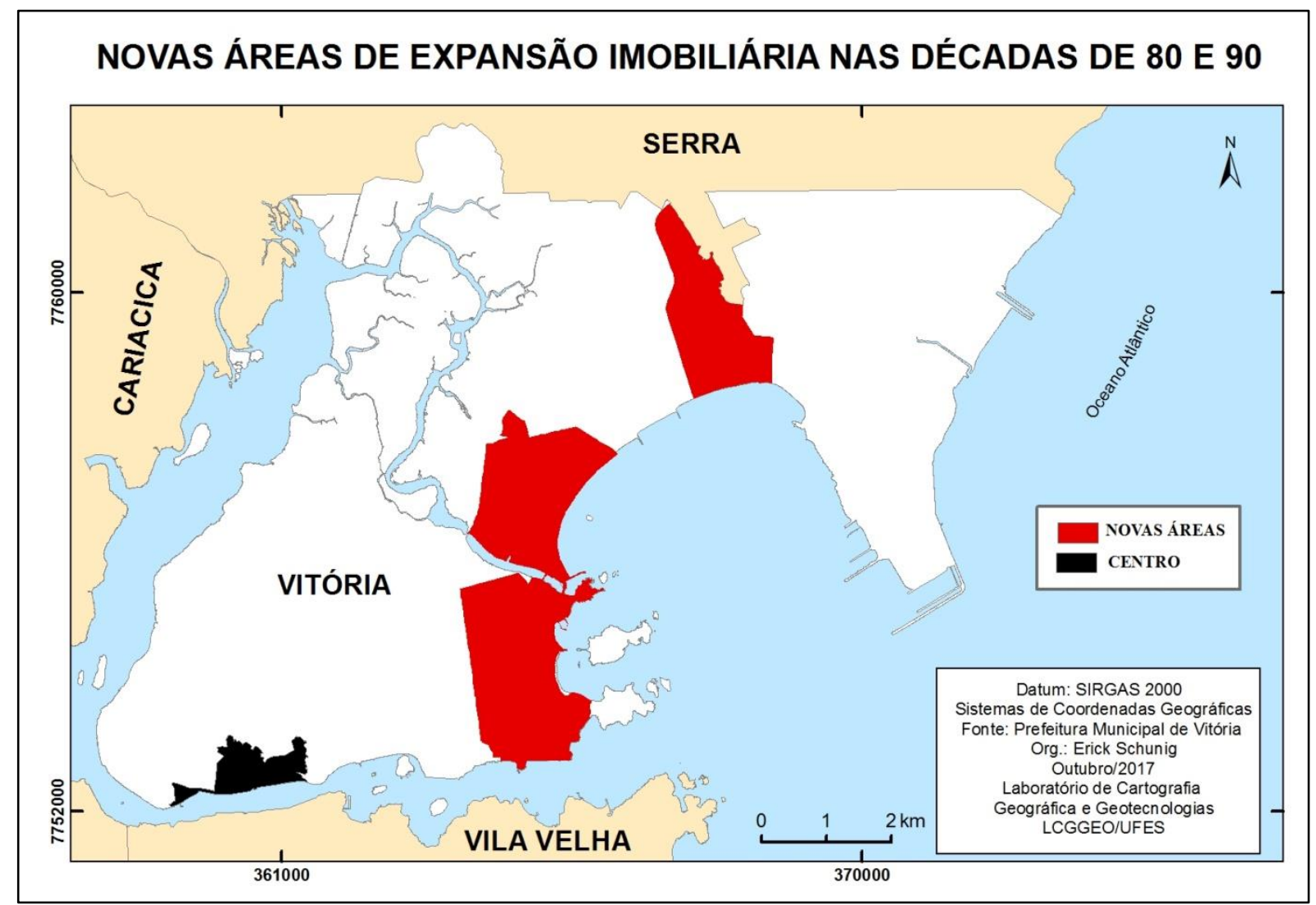

Figura 1 - As novas áreas de expansão do mercado imobiliário e o Centro de Vitória.

\section{A PROPAGANDA INDICANDO UMA NOVA REPRESENTAÇÃO DO ESPAÇO DO ALIMENTO}

A partir da década de 1980, observaram-se nos anúncios publicitários algumas mudanças em relação à representação da cozinha como espaço do alimento. Acreditamos que em função da crise econômica o setor da construção passou a elaborar estratégias a fim de criar novos conceitos e, consequentemente, novos diferenciais ao produto imobiliário.

Nesse aspecto, destacamos o diálogo entre a racionalização e a arquitetura, estabelecido em décadas anteriores, envolvendo a junção da copa e da cozinha como um espaço único. O conceito de copa-cozinha se observa na propaganda do edifício Pontevedra (Figura 2), na qual é um dos elementos de destaque no texto publicitário.

Estudos Geográficos, $\quad$ Rio $\quad$ Claro, $\quad 16(2)$ : $\quad 64-86, \quad$ jul./dez. $2018 \quad$ (ISSN 1678 -698X) http://www.periodicos.rc.biblioteca.unesp.br/index.php/estgeo 


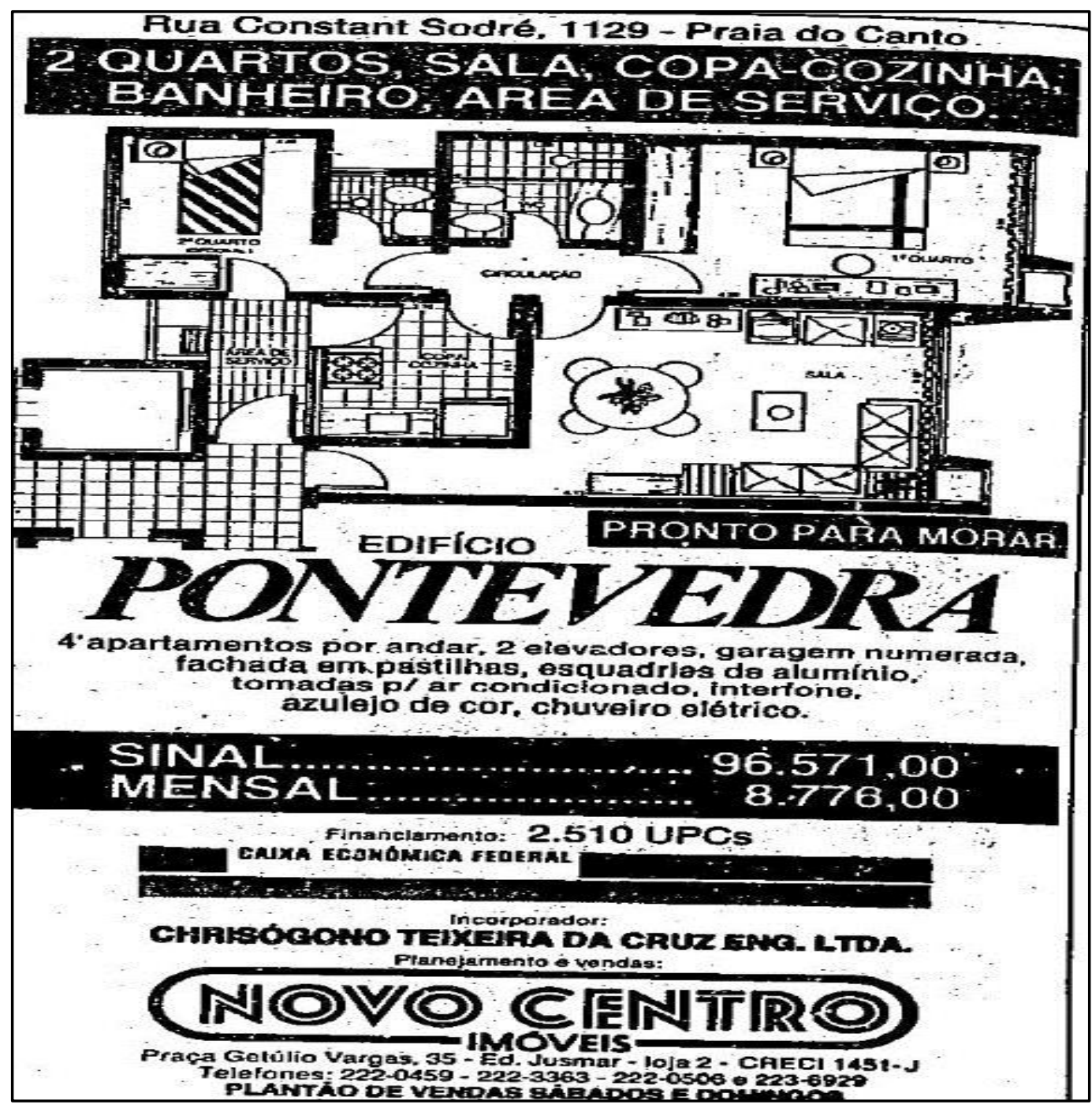

Figura 2 - Propaganda do edifício Pontevedra veiculada no jornal A Gazeta

Em face da retração do mercado imobiliário devido às condições econômicas da década de 1980 e à elevação do preço da terra, a copa-cozinha foi alçada a um item diferencial, simbolizando ao mesmo tempo as transformações do espaço urbano da cidade, no qual ganhou destaque o bairro Praia do Canto em detrimento do Centro de Vitória. A copa como item separado desaparece dos anúncios, não se constituindo num elemento diferencial. A copa-cozinha é um indicativo de um modo de vida no qual o indivíduo é submetido a racionalidade formal, cujo tempo passou a ser escasso até mesmo para fazer suas refeições em casa, perante aos ditames do cotidiano instaurado na capital capixaba.

Essa racionalidade à qual o espaço do alimento foi submetido também trouxe indicativos de mudanças no setor da construção imobiliária. A elevação do preço da terra somada à retração do mercado imobiliário nesse período condicionou seus agentes a realizarem estratégias visando à atração de um segmento que dispusesse de condições para adquirir o imóvel.

A partir da formação de uma nova classe média impulsionada pelos grandes projetos e da identificação de novas áreas a expansão imobiliária se tornou possível. Todavia, o setor imobiliário também produziu novos atrativos com a criação de itens que se coadunavam com o cotidiano desse novo segmento da população. Para uma

Estudos Geográficos, $\quad$ Rio $\quad$ Claro, $\quad 16(2): \quad 64-86, \quad$ jul./dez. $2018 \quad$ (ISSN 1678 - 698X) http://www.periodicos.rc.biblioteca.unesp.br/index.php/estgeo 
população que agora precisava se deslocar para distâncias maiores e começava a dispor de pouco tempo para ficar na residência, tais itens foram percebidos como diferenciais. Um aspecto desse indicativo pode ser observado no anúncio do edifício Pontevedra, no qual, além do acabamento, são ressaltados elementos que passaram a se constituir fundamentais para a vida num apartamento, como: os elevadores, a garagem e a área de serviço.

Também é possível inferir que tal flexibilidade espacial proposta pelo setor da construção imobiliária introduziu no espaço doméstico, em especial a cozinha, uma funcionalidade submetida ao tempo do trabalho. A década de 80 na cidade de Vitória marcou a consolidação das novas áreas de expansão do mercado imobiliário para o Norte da capital capixaba em detrimento da sua tradicional área central. $\mathrm{O}$ bairro Praia do Canto passou a ser o principal produto do mercado imobiliário e a orla do balneário de Camburi já contava com vários bairros como Jardim da Penha e Mata da Praia.

A consolidação desses novos espaços representou também uma mudança no cotidiano dos habitantes da capital. Aumentaram os deslocamentos para o trabalho, para compras ou mesmo para o lazer. A ideia de coletividade de lazer até então existente ganhou outro sentido que agora passava por uma vida intramuros, na qual os espaços de reunião ganhavam outro significado.

Observamos nas propagandas da década de 1980 a inserção desse conceito funcional, não somente na copa-cozinha, mas também a partir de outros conceitos como a ideia de "cozinha americana", difundindo um modelo de espaço amplo, com uma ou duas paredes em bancada, dispondo de armários embutidos, janelas e geladeira. Ao centro, uma bancada com armário, pia e fogão com coifa sobre este, e um espaço de circulação em volta de toda a bancada central.

$\mathrm{Na}$ introdução de novos conceitos pela propaganda, também observamos o destaque dado a equipamentos externos ao imóvel, que se relacionavam diretamente com a cozinha e que foram alçados a uma categoria como elementos diferenciais. Tal como pode ser visto na propaganda do edifício Skorpios (Figura 3), o texto enfatiza os atributos internos do apartamento, tais como copa-cozinha e gás central. Contudo, o discurso publicitário também destaca a localização e os equipamentos presentes, relacionando-os a uma necessidade de "viver com muito conforto".

Estudos Geográficos, $\quad$ Rio $\quad$ Claro, $\quad 16(2): \quad 64-86, \quad$ jul./dez. $2018 \quad$ (ISSN $\quad 1678$-698X) 


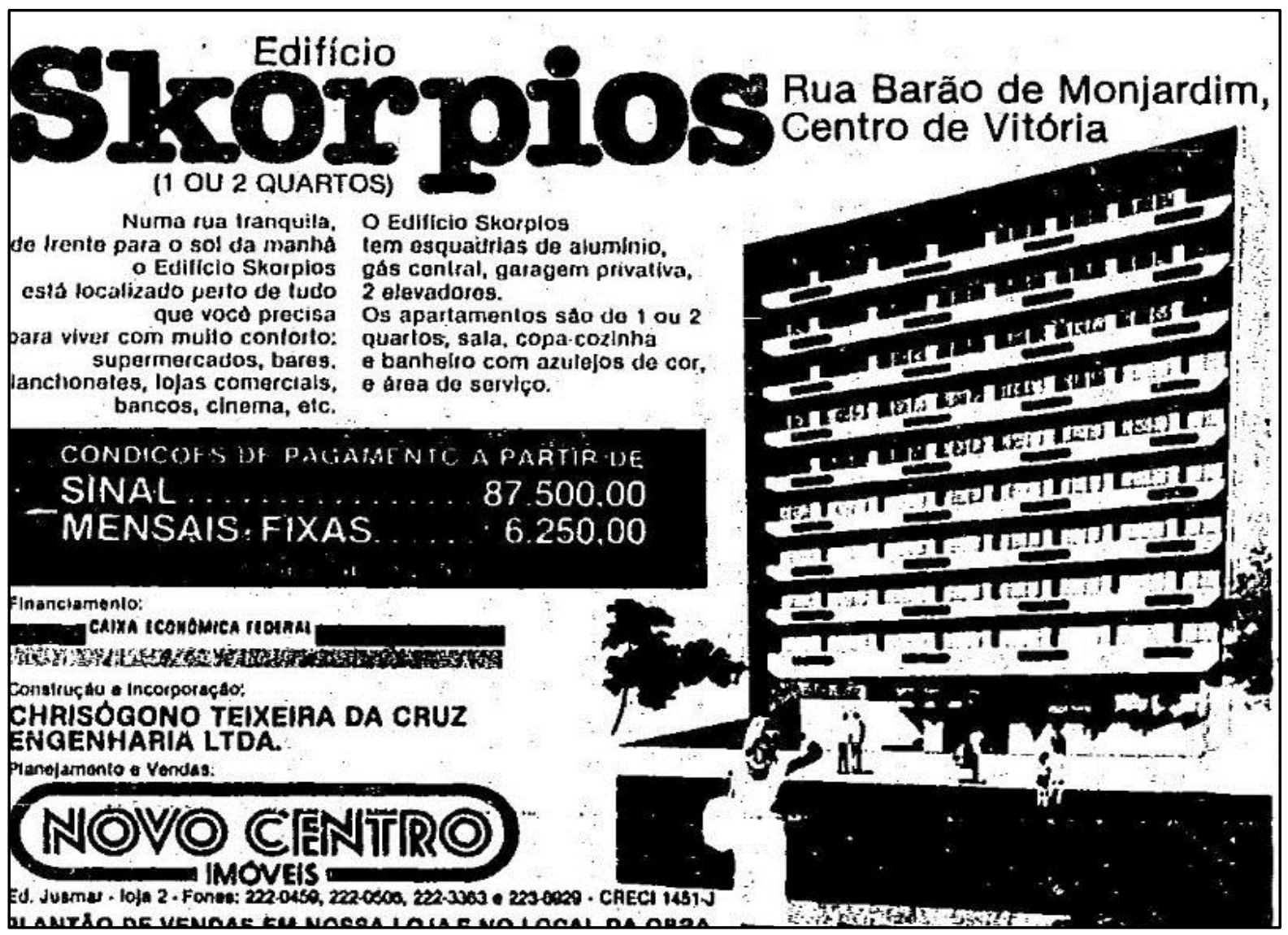

Figura 2 - Propaganda do edifício Skorpios veiculada no jornal A Gazeta

Nesse aspecto, destacavam-se os supermercados, bares, as lanchonetes, lojas comerciais, os bancos e o cinema. Depreende-se que a ênfase dada a esses elementos era um forte indicativo de mudanças no cotidiano da população da cidade de Vitória, que agora tinha seu tempo mais fugidio ante a forma de organização do trabalho e a consequente maneira como as pessoas passavam a se relacionar. Morar perto destes itens passava a ser sinônimo de "conforto", tal como aparece no texto do referido anúncio, pois representa maior disponibilidade de tempo para 0 lazer, para as atividades diárias e para obter o alimento.

O conceito de estar próximo a bares e lanchonetes indicava que as pessoas podiam fazer suas refeições de forma mais rápida, ao passo que induzia um novo conceito de lazer no cotidiano submetido ao tempo do trabalho. Começava a ganhar adesão a ideia de que a alimentação não precisava mais ser feita na residência, transformando-se numa tendência nas décadas posteriores a partir da difusão dos fast foods e dos restaurantes self service. A cozinha, como lugar de alimentação e da reunião familiar, começava a ter equipamentos concorrentes.

No que tange ao supermercado, observamos que a sua presença nas propagandas imobiliárias remetia à concepção de um equipamento privado, cuja consolidação produzia uma nova dimensão do ato de se alimentar e de preparação dos alimentos. Elo fundamental com a indústria, o supermercado estabelece uma relação com segmentos industriais como o de alimentos ultraprocessados ou de novidades direcionados a cozinha, como eletrodomésticos. Elementos que se coadunam com a rapidez estabelecida pelo tempo do trabalho.

O supermercado também expressa a ideia de personalização, da escolha do alimento e da proximidade de aquisição, desde que o consumidor adquirisse 0 Estudos Geográficos, Rio Claro, 16(2): 64-86, jul./dez. $2018 \quad$ (ISSN $\quad$ 1678-698X) http://www.periodicos.rc.biblioteca.unesp.br/index.php/estgeo 
imóvel com esse diferencial. Tanto na cidade de Vitória como em todo Brasil a espiral inflacionária foi uma constante na década de 1980. Essa situação ajudou na consolidação do supermercado como equipamento de primeira necessidade da população, que passou a estocar comida a partir da realização das famosas "compras do mês". Sem dúvida a crise dos anos 80 foi um ingrediente fundamental no padrão do consumo e ajudou na consolidação do supermercado dotado de uma funcionalidade na aquisição do alimento, em comparação com outros itens como: o açougue, a mercearia, a padaria e a feira.

A partir da década de 1990, os anúncios trouxeram novos elementos sobre a forma como o espaço do alimento seria apresentado nos apartamentos. Na maioria dos anúncios analisados desse período, notou-se que os empreendimentos estavam localizados em bairros da parte norte do município de Vitória, como: Praia do Canto, Jardim da Penha e Jardim Camburi, seguindo uma tendência que se inicia na década de 1970. Em contrapartida, não identificamos nenhum anúncio de empreendimentos construídos no Centro de Vitória, o que demonstra de descentralização ocorrido na cidade.

Nas propagandas da década de 1990 é possível observar uma tendência que acentuou nas décadas posteriores: a cozinha perde a primazia de ser o espaço de consumo dos alimentos. A copa-cozinha, outrora apresentada como um item diferenciado nas propagandas, já não se constituía mais numa novidade a fim de chamar a atenção de compradores. Tornou-se um item básico, que já não despertava mais atenção como elemento da vida moderna na capital capixaba. Contudo, outros elementos começavam a ganhar destaque, estabelecendo uma relação entre alimentação e lazer.

Nesse período verificou-se o aparecimento de outros espaços externos à cozinha com destaque não somente no preparo e consumo de alimentos, mas como um local de encontro e de lazer. Um exemplo dessa característica está relacionado à propaganda do edifício Rocca Porena (Figura 4). Nela é possível observar através do texto publicitário que se dá destaque a elementos como a churrasqueira, o bar e a copa dentro de uma área de lazer. Os signos apresentados nesse anúncio trazem agora um conceito de habitação como um lugar de diversão e segurança, na tentativa de resgatar aspectos que se perderam a partir da racionalidade formal presente na vida urbana de cidades como Vitória, como a vida num bairro.

O discurso publicitário enfatiza elementos como a "localização privilegiada" ao mesmo tempo em que destaca outros aspectos como a igreja, a origem do nome em homenagem a uma santa, o vilarejo na Itália e a existência da área de lazer como um espaço de convivência. Podemos inferir que os signos utilizados pela propaganda procuram resgatar a lembrança de aspectos duma vizinhança que existia em tempos pretéritos, quando as pessoas interagiam com mais intensidade nas festividades ou mesmo através da informalidade cotidiana.

Esse novo conceito referente o lazer presente nas propagandas imobiliárias da década de 1990 tem como um dos seus signos mais importantes a churrasqueira. Item que não existia nas propagandas de décadas anteriores, ela simboliza o lazer através do convívio de grupos que estão se adaptando a vida intramuros na medida em que percebem a rua como um espaço ameaçador e sem resquícios da vizinhança que a maioria conheceu em sua infância.

A churrasqueira é a tentativa de resgate do ritual, da celebração, do momento de encontro no qual o tempo permitia momentos de maior contato com a família e amigos. Trata-se de um equipamento que simboliza um tipo de coletividade

Estudos Geográficos, Rio Claro, 16(2): 64-86, jul./dez. $2018 \quad$ (ISSN $\quad$ 1678-698X) http://www.periodicos.rc.biblioteca.unesp.br/index.php/estgeo 
que se tornou escasso em função do tempo do trabalho. Todavia, os destaques dados à churrasqueira e a outros itens como a varanda marcam o fim da singularidade da cozinha como espaço do alimento nos apartamentos residenciais.

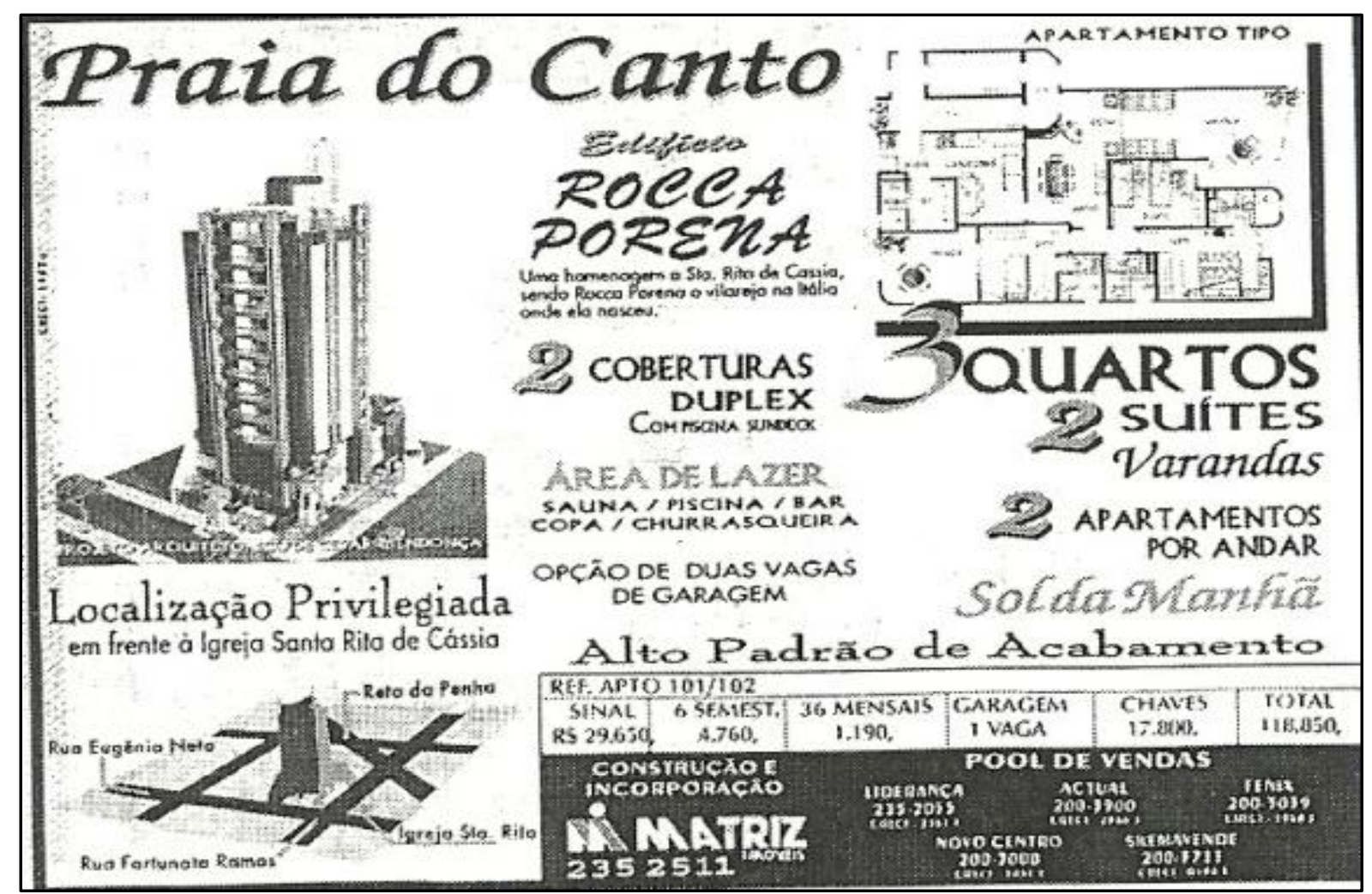

Figura 3 - Propaganda do edifício Rocca Porena veiculada no jornal A Gazeta

Esse aspecto pode ser observado na propaganda do edifício Artemis (Figura 4), na qual o discurso publicitário se refere ao lazer e a felicidade a partir de elementos como o salão de festas, a churrasqueira, a área recreativa, a piscina e a varanda. Esta última é mencionada em vários anúncios, o que nos levou a concluir que a vida intramuros nos apartamentos induzia à racionalidade com que o processo construtivo elegeria novos espaços como itens diferenciais.

O discurso publicitário do edifício Artemis utilizou signos que associam colunas gregas a momentos de família e reuniões de amigos denotando um conceito de requinte e beleza ligados à ideia de felicidade contida num espaço dotado de singularidades. Tais singularidades são apresentadas pelos itens descritos, dos quais à cozinha já não fazia mais parte. Porém, o espaço do alimento não foi esquecido, mas sim ressignificado através da churrasqueira e de outros equipamentos de lazer que denotassem modernidade (aterramento para computador) ou exclusividade ( $3^{\underline{a}}$ garagem opcional e hidrômetros independentes).

Estudos Geográficos, $\quad$ Rio $\quad$ Claro, $\quad 16(2)$ : $\quad 64-86, \quad$ jul./dez. $2018 \quad$ (ISSN 1678 -698X) http://www.periodicos.rc.biblioteca.unesp.br/index.php/estgeo 


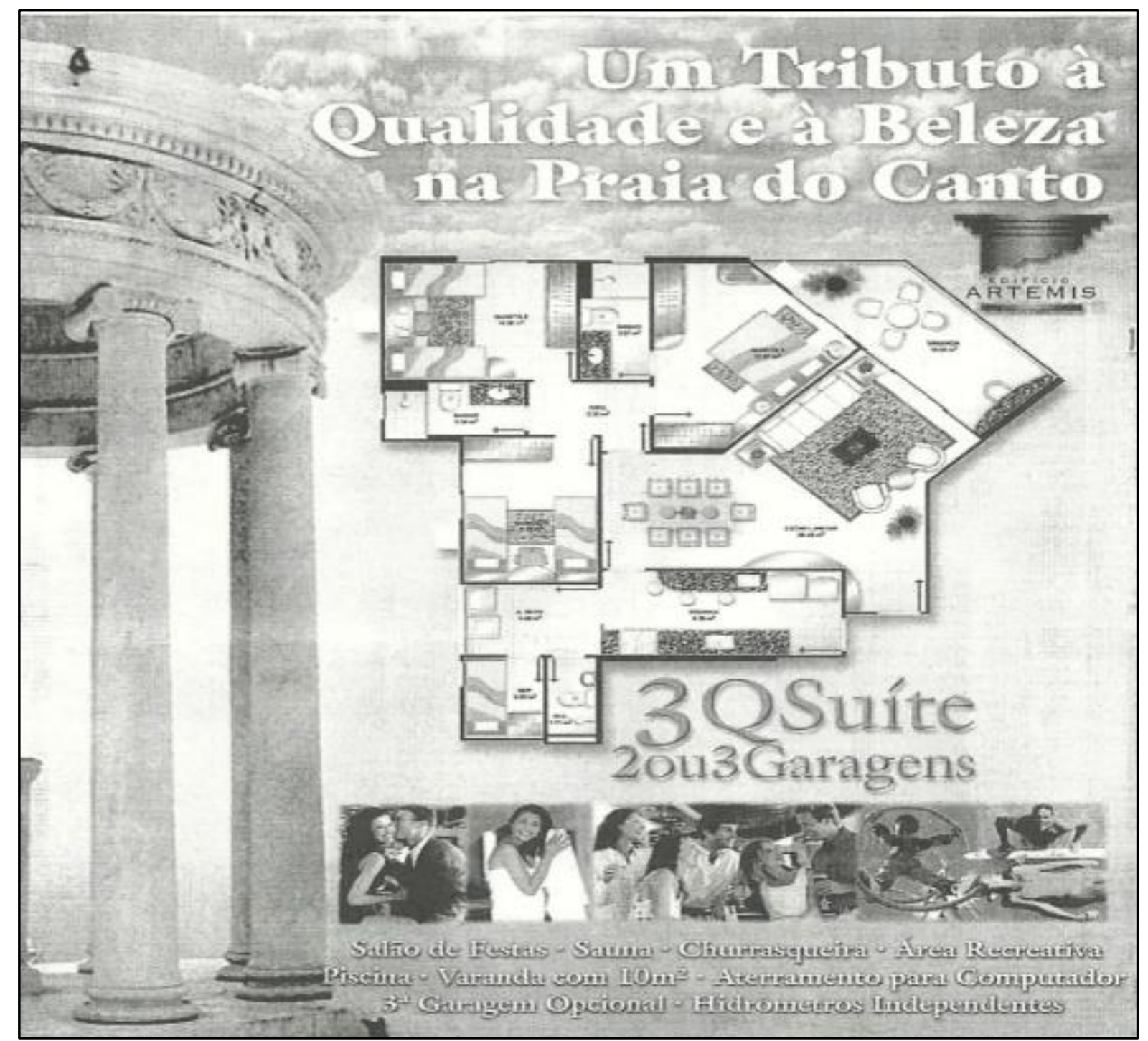

Figura 4 - Propaganda do edifício Artemis veiculada no jornal A Gazeta

O destaque dado pelo discurso publicitário do anúncio no tocante à churrasqueira, à varanda e ao salão de festas, apresenta uma tendência consoante à saída do espaço do alimento da cozinha. Uma vez que o mercado imobiliário se reestruturava na década de 1990, as estratégias do setor da construção imobiliária objetiva a projeção de rendimentos crescentes e para tal, novos itens foram apresentados como novos espaços de reunião e de alimentação. Essa tendência seria consolidada por meio de outros conceitos na década posterior.

Acreditamos que essa primazia perdida pela cozinha se inseria num contexto da década de 1990 que envolvia a estabilização econômica e uma mudança de hábitos alimentares que não abarcava somente em Vitória. O novo cotidiano produzido pela racionalização do capitalismo levou as pessoas a se alimentarem cada vez mais fora de sua residência. $O$ tempo do trabalho condicionava os membros da família, agora menos numerosa, a não estarem juntos em todas as refeições.

As referências alimentares trazidas pelo convívio familiar também vão sendo obliteradas aos poucos. As referências maternas das receitas tradicionais vão cada vez mais sendo deixadas de lado. Comer bem passou a ser sinônimo de comer

Estudos Geográficos, $\quad$ Rio $\quad$ Claro, $\quad 16(2): \quad 64-86, \quad$ jul./dez. $2018 \quad$ (ISSN 1678 - 698X) http://www.periodicos.rc.biblioteca.unesp.br/index.php/estgeo 
fora de casa, representando uma inversão de referencial, já que a indústria, o restaurante e o supermercado passam a ser o referencial e não mais a família. $O$ alimento feito em casa e a cozinha começavam a perder importância diante da praticidade das refeições rápidas e dos alimentos congelados e ultraprocessados.

Percebemos que dentro das estratégias estabelecidas pelos agentes imobiliários, difundia-se a ideia de que o espaço do alimento deveria ser um lugar de lazer e que poderia sair do apartamento. Este passava agora a ser adaptado às novas regras de convívio de um tempo submetido à racionalização. A redução da metragem dos apartamentos levou o espaço do alimento a sair do apartamento a fim de ganhar novos significados. Por outro lado, revelou o esvaziamento do cozinhar como um elemento do cotidiano.

\section{CONSIDERAÇÕES FINAIS}

Dentro da proposta que envolve este trabalho, nossa análise encontrou indicativos nos quais é possível observar uma conexão entre as mudanças na cozinha dos apartamentos da cidade de Vitória e a transformação do cotidiano de seus habitantes. Nesse processo, as ações provocadas pelo setor da construção imobiliária envolvendo a ressignificação da cozinha conectaram-se à estratégia de outros segmentos, a exemplo da indústria alimentícia.

Notamos também que o fim da primazia da cozinha como espaço do alimento envolveu a utilização de outros itens, que ganharam projeção no período analisado, como a churrasqueira e a varanda. $O$ destaque dado a esses equipamentos nas propagandas antecipam uma nova tendência em décadas seguintes no que concerne à criação de espaços diferenciados para reunião da família e de amigos.

A partir da leitura do mito apresentada por Barthes (1980), observou-se que a ação do setor da construção imobiliária passa pela seleção de elementos da realidade e sua legitimação. A propaganda recorre ao desejo que vai para além da aquisição do imóvel, pois envolve ao apelo à distinção (BOURDIEU, 2007) e à funcionalidade permitida pela personalização (BAUDRILLARD, 1995) num cotidiano produzido pelo Capitalismo.

Nesse cotidiano o habitat foi apresentado pela propaganda imobiliária como um espaço dotado de singularidades que o expuseram como o lugar da felicidade. Contudo, tal como ressaltam Harvey (2013) e Lefebvre (2000; 2008a; 2008b), a estratégia do setor da construção imobiliária envolve a utilização do imaterial, como possibilidade de inserção de bens culturais que se tornaram raridades em função da dinâmica da sociedade atual. Dessa forma, a tradição culinária tornou-se um item passível de apropriação e materialização no espaço concebido, que necessariamente já não precisa ser mais a cozinha diante da lógica que domina a vida moderna.

No caso da alimentação, os sistemas de racionalidade nos apresentam signos da idealização da vida moderna (fast food, supermercados). A racionalidade percebida na cozinha com espaço do alimento é mais que um item atrelado a diversas cadeias produtivas da sociedade de consumo. Constitui-se na verificação de que a nossa relação com o alimento foi submetida a uma racionalização, tal como ocorre em toda sociedade.

Acreditamos que é possível inferir que está racionalização induz a um fetiche acerca da alimentação, levando-a um retorno à tradição alimentar do passado, mas

Estudos Geográficos, Rio Claro, 16(2): 64-86, jul./dez. $2018 \quad$ (ISSN $\quad$ 1678-698X) http://www.periodicos.rc.biblioteca.unesp.br/index.php/estgeo 
que agora é mediado pela indústria. Novos produtos são apresentados pela globalização, ao passo que novos gostos são difundidos e padronizados, mas, também, produzem diferenciações, contradições e conflitos. O próprio elemento estético de diferenciação, o gosto, foi reapresentado, naturalizando sentidos e formas flutuantes aos ventos da lógica mercantil.

A ausência de comportamento crítico revela um olhar sobre o urbano formado pela prática e pela teoria da industrialização, que reduz a realidade em formação. Analisamos esses elementos a partir da difusão dessa retórica mediada pela propaganda. Nesse processo, a cozinha perdeu a primazia como espaço do alimento.

Em nossa análise, percebemos que essa mudança em relação ao espaço do alimento revelou a produção de um espaço urbano regido por uma nova lógica do cotidiano e do lar. Ocorreu uma ruptura com a memória familiar, ao mesmo tempo em que foram produzidos novos aromas e formas visando à substituição ou apropriação dessa memória, ditada agora pela propaganda.

Ao final deste período estudado, a tendência de substituição da cozinha como espaço do alimento, observada nas propagandas, apresenta novos elementos para discussão, que abarcam a ressignificação do ato de cozinhar e a apresentação do alimento como um novo produto, através do gourmet. Questão que envolve diversos outros elementos relacionados ao alimentar e que devem ser analisados.

\section{REFERÊNCIAS}

A GAZETA. Vitória. no 15717. A Gazeta classificados. p1 - 9, 7 jun. 1981.

Vitória. ํㅜ15863. A Gazeta classificados. p 1 - 10, 1 nov. 1981.

. Vitória. n 23105. A Gazeta Classificados. p 1 - 20, 8 set. 1996.

Vitória. nํ24345. A Gazeta classificados. p 1 - 22, 7 nov. 1999.

BAUDRILLARD, Jean. A sociedade de consumo. Trad Artur Morão. Rio de Janeiro/Lisboa: Elfos/Edições 70, 1995. 216p.

Simulacros e simulações. Trad. Maria João da Costa Pereira. Lisboa: Relógio d’Água, 1991. 201p.

BARTHES, Roland. Mitologias. Trad. Rita Buongermino e Pedro de Souza. 4 ed. São Paulo: Difel, 1980. 180p.

BOTELHO, Adriano. O urbano em fragmentos: a produção do espaço e da moradia pelas práticas do setor imobiliário. São Paulo: Annablume, 2007. 315p.

BOURDIEU, Pierre. A distinção - crítica social do julgamento. Trad. Daniela Kern e Guilherme Teixeira. São Paulo: Edusp, 2007. 560p.

CAMPOS JÚNIOR, Carlos T. A produção da cidade. Vitória: Florecultura, 2002. $192 p$.

Estudos Geográficos, Rio $\quad$ Claro, $\quad$ 16(2): $\quad$ 64-86, $\quad$ jul./dez. $2018 \quad$ (ISSN $\quad 1678$-698X) http://www.periodicos.rc.biblioteca.unesp.br/index.php/estgeo 
COSTA, André. A imagem da arquitetura e a arquitetura da imagem: uma investigação acerca da construção dos discursos na produção do espaço urbano. 2002. 164 f. Dissertação (Mestrado em Arquitetura e Urbanismo) - Programa de Pós-Graduação da Faculdade de Arquitetura e Urbanismo, Universidade de São Paulo, São Paulo. 2002.

CONSELHO EXECUTIVO DAS. NORMAS-PADRÃO (CENP). Normas-padrão da atividade publicitária. São Paulo: CENP, 2003. Disponível em: <http://www.cenp.com.br/PDF/NomasPadrao/Normas_Padrao_Portugues.pdf>. Acesso em: 12 jun 2015.

FISCHLER, Claude. El (h)omnívoro - el gusto, la cocina y el cuerpo. Barcelona: Editora Anagrama, 1995. 424p.

HARVEY, David. Ciudades rebeldes - del derecho de la ciudad a la revolucion urbana. Madrid: Ediciones Akal, 2013. 296p.

JARAMILLO, Samuel. Las formas de producción del espacio construido en Bogotá. In: PRADILLA, Emilio. (Org) Ensaios sobre el problema de la vivenda en México. México: Latina UNAM, 1982, p. 149-212.

KOTLER, Philip. Administração de Marketing. Trad. Bazán Tecnologia e Linguística. 10. ed. São Paulo: Prentice Hall, 2000. 764p.

LEFEBVRE, Henry. A revolução urbana. Trad. Sérgio Martins. 3 ed. Belo Horizonte: UFMG, 2008a. 192p.

O direito à cidade. Trad. Rubens Eduardo Frias. 5 ed. São Paulo: Centauro, 2008b. 144p.

. La production de l'espace. 4 ed. Paris: Éditions Anthropos, 2000. 487p.

PLOEG, Jan Douwe Van Der. Camponeses e impérios alimentares: lutas por autonomia e sustentabilidade na era da globalização. Trad. Rita Pereira. Porto Alegre: UFRGS, 2008. 372 p.

POULAIN, Jean-Pierre. Manger aujourd'hui: attitudes, normes et pratiques. Editions Privat, Paris, 2001. 235p.

REIS, Luis C.T. dos. Descentralização e desdobramento do núcleo central de negócios na cidade capitalista: estudo comparativo entre Campo Grande e Praia do Canto, na Grande Vitória-ES. 2007. 286f. Tese (Doutorado em Geografia) Programa de Pós-Graduação em Geografia, Universidade Federal do Rio de Janeiro, Rio de Janeiro. 2007.

RITZER, George. La McDonalización de la sociedade - un análisis dela racionalización en la vida cotidiana. Barcelona: Editorial Ariel, 1996. 256p.

SCARIM, Paulo Cesar. Territorialidades em conflito na construção do espaço agrário capixaba: o desenvolvimento em questão. 2006. 219 f. Tese (Doutorado em

Estudos Geográficos, $\quad$ Rio $\quad$ Claro, $\quad 16(2): \quad 64-86, \quad$ jul./dez. $2018 \quad$ (ISSN 1678 -698X) 
ordenamento territorial e ambiental) - Programa de Pós-Graduação em Geografia, Universidade Federal Fluminense, Niteroi. 2006.

SCHUNIG F., Erick $A$. O recurso da propaganda na valorização do produto imobiliário nos municípios de Vitória e Serra a partir da segunda metade do século XX. 2014. 245p. Dissertação (Mestrado em Geografia) - Programa de PósGraduação em Geografia do Departamento de Geografia da Universidade Federal do Espírito Santo. 2014.

SCHUNIG F, Erick A.; SCARIM, Paulo C. A representação da cozinha como elemento do produto imobiliário na cidade de Vitória entre as décadas de 1950 a 1970. Revista Geografares, v. 23, Vitória, 2017. p. 94-108.

STASZAK Jean-François. L'espace domestique: pour une géographie de l'intérieur. In: Annales de Géographie, t. 110, n620, 2001. p. 339-363.

TOPALOV, Christian. La urbanizacion capitalista - algunos elementos para su análisis. México: Edicol, 1979. 137p.

Artigo submetido em: 13/12/2017

Aceito para publicação em: 04/11/2018

Publicado em: 14/12/2018

Estudos Geográficos, Rio Claro, 16(2): $\quad$ 64-86, jul./dez. $2018 \quad$ (ISSN 1678 - 698X) 